University of Nebraska - Lincoln

DigitalCommons@University of Nebraska - Lincoln

Agronomy \& Horticulture - Faculty Publications

Agronomy and Horticulture Department

1967

\title{
A Bioassay for Detecting Compounds Which Stimulate or Deter Feeding by the Sweetclover Weevil
}

\author{
W. R. Akeson \\ University of Nebraska-Lincoln \\ G. R. Manglitz \\ United States Department of Agriculture \\ H. J. Gorz \\ United States Department of Agriculture \\ Francis A. Haskins \\ University of Nebraska-Lincoln, fhaskins@neb.rr.com
}

Follow this and additional works at: https://digitalcommons.unl.edu/agronomyfacpub

Part of the Plant Sciences Commons

Akeson, W. R.; Manglitz, G. R.; Gorz, H. J.; and Haskins, Francis A., "A Bioassay for Detecting Compounds Which Stimulate or Deter Feeding by the Sweetclover Weevil" (1967). Agronomy \& Horticulture -- Faculty Publications. 207.

https://digitalcommons.unl.edu/agronomyfacpub/207

This Article is brought to you for free and open access by the Agronomy and Horticulture Department at DigitalCommons@University of Nebraska - Lincoln. It has been accepted for inclusion in Agronomy \& Horticulture -Faculty Publications by an authorized administrator of DigitalCommons@University of Nebraska - Lincoln. 


\title{
A Bioassay for Detecting Compounds Which Stimulate or Deter Feeding by the Sweetclover Weevil ${ }^{1,2}$
}

\author{
W. R. Akisos, G. R. MANGititz, H. J. GoRz, and F. A. Haskins
}

\section{ABSTRACT}

A bioassay employing sweetclover root disks impregnated with various plant extracts has been developed. The bioassay has been userl to demonstrate the distribution of substances influencing feeding in fractionated water-methanol-chloroform extracts of Melilotus infesta
Guss. and $M$. officinalis L. Lam. leaves. Indications are that substances responsible for the resistance of $M$. in. festa or the susceptibility of $M$. officinalis to feeding by adult sweetclover weevils, Sitona cylindricollis Fåhraeus, reside in the water-methanol fraction.
Among 19 Melilotus species screcned by Manglity and Gor: (1964), M. infesta Guss. was the only species not fed upon to an appreciable extent by the adult sweetclover weevil, Sitona cylindricollis (Făhracous). The weevil resistance of $M$. infesta was confirmed by Gross and Stevenson (1964) and Radcliffe and Holdaway (1964).

Since the resistance of $M$. infesta is manifested by a refusil of the adult weevils to feed extensively on this species, it appears that resistance may result from either a lack of attractiveness or the presence of deterrent substances. Thus, studies to determine the chemical nature of this resistance should focus first on detecting substances which would stimulate or deter weevil feeding.

One prerequisite for a study of the chemical nature of resistance is at suitable bioassay for selecting biologically active fractions in various plant extracts. This paper clescribes such a bioassay and gives results obtained from preliminary experiments using the bioassay.

Matrialals and Mktholns.-One of the first requirements in the development of an effective bioassay is a suitable means of presenting the extracts or frac-tions to the weevils for feeding. For a bioassay involving the sweetclover weevil, which leeds exclusively from the leaf margins, the requirements for the feeding medium are: (a) the medium must be thin enough to allow feeding on the edges lout rigid enough to support the weight of the weevils; (b) the consistency of the medium must permit chewing by

\footnotetext{
1 Colcoptera: Curculionidac.

*A cooperative investigation lxtwe'n the Nebraska Agricultural lixperiment Station. University of Nebraska, Lincoly, and the FnServ., LSDA. Supported in part by ARS Grant no. 12-14-1008027 (33). Contribution no. 280 of the Department of Entomology. Iniversity of Nebraska. Published with approval of the Directo as Paper no. 2028, Journal Series, Nebraska Agricultural Experiment Station. Accepted for publication April 16,1967

"Assistant Professor of Agronomy, University of Nebraska; Rcscarch Entomologist, Entomology Rcsearch Division, Agr. Res. Serv. USDA: Research (ieneticist. Cirops Research Division, Agr. Res. Serv.. USDA; and Professor of Agronomy, University of Nebraska respectively.
}

the weevil; (c) the medium must be relatively inert so as to prevent appreciable feeding on the untreated material and to avoid the presence of substances which alter the feeding response of the weevil to the active chemical components; and (d) except for changes caused by feeding, the material should remain constant in size and shape so that the extent of feeding can be readily determined. Many materials. including pith from the Japanese elder as used by Thorsteinson (1955), agar blocks, and disks of potato tuber, carrot, sweet potato roots, cabbage, and celery hearts were tested as media for the bioasay, but all were unsuitable with respect to one or more of the foregoing requirements. Disks cut from sweetclover roots and subjected to certain pretreatments are the most satisfactory of the bioassay media thus far tested.

First-year plants of field-grown Evergreen swettclover (M. alba Desr.) provided the roots used in preparing the bioassay disks. The plants were dug in November 1965, and fleshy branch roots from 12 to $15 \mathrm{~mm}$ in diam were selected. Sections approximately $20 \mathrm{~mm}$ long, cut from the central portion of these roots with a $9-\mathrm{mm}$ cork borer, were sliced into disks $0.1 \mathrm{~mm}$ thick with a hand microtome. The disks were washed several times in clistilled water. suspended in water $(50 \mathrm{ml} / 300$ disks) in a $250-\mathrm{ml}$ flask, frozen, and lyophilized. To inactivate enzymes and remove alcohol and chloroform-soluble constituents, the lyophilized disks were refluxed for $4 \mathrm{lir}$ with boiling $100 \%$ ethanol followed by $4 \mathrm{hr}$ of extraction with chloroform and $4 \mathrm{hr}$ with methanol in a Soxhlet thimble. After treatment, the disks were stored under methanol at $-20^{\circ} \mathrm{C}$ until used.

Prior to use in the bioassay, disks were attached to no. I stainless-steel insect pins cut to a length of $13 \mathrm{~mm}$. The 5 disks used for each treatment were placed in a 50-mm watch glass containing 0.15 to I inl of plant extract which had been evaporated nearly to dryness under vacuum. Sufficient water was added to nonaqueous cxtracts or fractions so that the clisks wcre still damp after the organic solvents had evaporated. Petri plates $15 \mathrm{~mm}$ deep and 95 or 145 
Table 1.-Feeding preference of the sweetclover weevil III sweetclover root disks treated with water-methanol or thloroform phases of a methanol-chloroform-water extract of swcetclover leaves.

\begin{tabular}{|c|c|c|c|c|c|}
\hline \multirow[b]{2}{*}{ Triatment } & \multicolumn{4}{|c|}{$\begin{array}{l}\text { Percent disk area consumed } \\
\text { in each test }{ }^{\mathrm{a}}\end{array}$} & \multirow[b]{2}{*}{$A v g^{b}$} \\
\hline & I & II & III & IV & \\
\hline \multicolumn{6}{|c|}{ 1. Comparison of same phase from 2 different species } \\
\hline \multicolumn{6}{|c|}{ Water-methanol phase (Group I) } \\
\hline $\begin{array}{l}\text { Tiluent check } \\
\text { M. injes/a } \\
\text { M. offirinalis" }\end{array}$ & $\begin{array}{r}3.0 \\
8.8 \\
26.7\end{array}$ & $\begin{array}{r}5.4 \\
7.0 \\
52.4\end{array}$ & $\begin{array}{r}8.2 \\
6.0 \\
40.6\end{array}$ & $\begin{array}{r}5.2 \\
3.0 \\
61.3\end{array}$ & $\begin{array}{r}5.5 \mathrm{a} \\
6.3 \mathrm{a} \\
45.3 \mathrm{~b}\end{array}$ \\
\hline \multicolumn{6}{|c|}{ Chloroform phase (Group II) } \\
\hline $\begin{array}{l}\text { Suluent check } \\
\text { U. infestat } \\
\text {.H. u/firinalist }\end{array}$ & $\begin{array}{r}0.3 \\
31.3 \\
28.0\end{array}$ & $\begin{array}{r}1.2 \\
23.7 \\
24.3\end{array}$ & $\begin{array}{r}1.0 \\
30.3 \\
21.0\end{array}$ & $\begin{array}{r}4.7 \\
19.4 \\
20.4\end{array}$ & $\begin{array}{r}1.8 \mathrm{a} \\
26.2 \mathrm{~b} \\
23.4 \mathrm{~b}\end{array}$ \\
\hline \multicolumn{6}{|c|}{$\therefore$ Comparison of the 2 phases from same species } \\
\hline \multicolumn{6}{|c|}{ M. infesta extract (Group III) } \\
\hline $\begin{array}{l}\text { Dillent checke } \\
\text { Niller-methan } \\
\text { cilloroform pl }\end{array}$ & pliase & $\begin{array}{r}8.0 \\
1.7 \\
49.3\end{array}$ & $\begin{array}{r}2.3 \\
0.7 \\
62.3\end{array}$ & $\begin{array}{r}1.7 \\
2.0 \\
40.7\end{array}$ & $\begin{array}{r}4.0 \mathrm{a} \\
15 \mathrm{a} \\
50.7 \mathrm{~b}\end{array}$ \\
\hline \multicolumn{6}{|c|}{ M. officinalis extract (Group IV) } \\
\hline $\begin{array}{l}\text { volvent check } \\
\text { Witter-methan } \\
\text { cillonoform pl }\end{array}$ & plinased & $\begin{array}{r}4.3 \\
16.7 \\
46.3\end{array}$ & $\begin{array}{r}2.5 \\
23.0 \\
64.7\end{array}$ & $\begin{array}{r}0.0 \\
10.3 \\
39.0\end{array}$ & $\begin{array}{r}2.3 \mathrm{a} \\
16.7 \mathrm{~b} \\
50.0 \mathrm{c}\end{array}$ \\
\hline 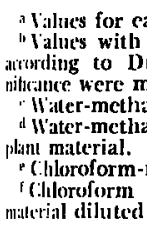 & 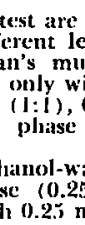 & $\begin{array}{l}\text { averages } \\
\text { ters diff } \\
\text { triple ra } \\
\text { thin gro } \\
\text { this ml. } \\
\text { (0.5) m }\end{array}$ & $\begin{array}{l}5 \mathrm{dis} \\
\text { signi }\end{array}$ & ting & $\begin{array}{l}\text { e } 1 \% \text { level } \\
\text { ns for sig- } \\
25 \mathrm{~g} \text { fresh } \\
\text { fresh plant } \\
\text { ater. }\end{array}$ \\
\hline
\end{tabular}

IIIm in diam were used in the bioassay. A 3-mm layer of melted paraffin was poured into each clish and allowed to harden. 'Ihis layer was covered with Will(r-moistence Whatman no. 3 filter paper, and the pins holding the disks were mounted upright in the jaralfin.

Plint extracts used in the development of the bioassiy were obtained from fresh young leaves of greenlouse-yrown plants of the susceptible species, $\boldsymbol{M}$. offlimalis L. Lam. (variety Goldtop), and the species resistant to swectclover weevil feeding, $M$. infesta. ('lloroform-methanol-water extracts were found to nive the best fecding response anong the various lyes of extracts prepared and thus were used in bioassay development. In preparing these extracts, a modification of the method of Bligh and Dyer (1959) miss used. Fifty g of fresh young leaflets were homoounized for 5 mins under a nitrogen atmosphere with $150 \mathrm{ml}$ of chloroform-methanol $(1: 2, \mathrm{v} / \mathrm{v})$. Ilicr addition of $50 \mathrm{ml}$ of chloroform, the preparation was homogenized for another $30 \mathrm{sec}$. The mixIIIre was homogenized for a final 30 -sec period after aldition of $50 \mathrm{ml}$ of water. The homogenate was fitcred with a slight vacuum until the residue was wearly dry. The water-methanol phase (upper) was separaterl from the chloroform phase and washed with $100 \mathrm{ml}$ of chloroform, while the chloroform plitise (lower) was washed with $180 \mathrm{ml}$ of waterinethinol $(4: 5, v i v)$. Washlings were added to simi- lar fractions from the original separation. The phases were concentrated under vacuum so that $2 \mathrm{ml}$ of the chloroform phase and $4 \mathrm{ml}$ of the water-methanol phase each represented $1 \mathrm{~g}$ of fresh plant material.

Weevils used in the assay had been collected in September and October of 1965 and stored in tightly closed cardboard containers at $2^{\circ} \mathrm{C}$. Weevils taken out of cold storage were held for 2 days without food and then allowed to feed for $24 \mathrm{hr}$ on root disks treated with crude plant extract to condition them for the bioassay. Weevils not conditioned in this manner often would not feed satisfactorily during the bioassay. Once conditioned to eating the treated root disks, the weevils could be used repeatedly. All bioassays were done at room temperature under fluorescent lights with a population of 2 weevils/disk. The duration of each test was $6 \mathrm{hr}$.

After the bioassay was completed, pins were removed and the remaining portions of disks were mounted on the adhesive side of Scotch Magic Transparent Tape. Dehydrated disks were moistened with water before being mounted, to restore them to their original size. The tape was applied to graph paper (20 grids/inch) and the original area of the disk was marked. The area consumed was then measured by counting squares on the graph paper. Data were expressed as percent of the total disk area consumed. This was essentially the method used by Calkins $^{\pi}$ (1964) for measuring weevil feeding on leaves.

Results and Discussion.-The results of 4 different groups of sweetclover wecvil feeding trials are presented in Table 1. Each group consisted of 3 or 4 successive feeding tests with 3 treatments or comparisons. The water-methanol phases of $M$. infesta and

4 Mention of a proprictary product does not necessarily imply its

cudorsement by the USDA. feeding rates of the sweetcluver weevil. AI. S. thesis. University of Nebraska.

Table 2.-Feeding by sweetclover weevils on sweetclover root disks treated with chloroform or combined chloroform and watermethanol phases of $M$. infesta and M. officinalis extracts.

Pcrcent disk area consumed in each test ${ }^{a}$

\begin{tabular}{|c|c|c|c|}
\hline & & & \\
\hline Treatment & I & II & Avg" \\
\hline 1. Solvent check" & 0.0 & 4.0 & $2.0 \mathrm{a}$ \\
\hline $\begin{array}{l}\text { M. Minfesta- } \\
\text { chloroform phased }\end{array}$ & 11.7 & 12.0 & $11.9 \mathrm{ab}$ \\
\hline $\begin{array}{l}\text { 3. M. oflcinalis- } \\
\text { chloroform phased } \\
\text { 4. M. infesta-combined }\end{array}$ & 21.6 & 13.7 & $17.7 \mathrm{~b}$ \\
\hline $\begin{array}{l}\text { chloroform and water- } \\
\text { methanol phasese } \\
\text { 5. M. officinalis-combined }\end{array}$ & 23.0 & 16.0 & $19.5 \mathrm{~b}$ \\
\hline methanol phasese & 52.3 & 52.6 & $52.4 \mathrm{c}$ \\
\hline
\end{tabular}

a Values for each test are averages of 5 disks.

b Values with different letters differ significiantly at the $1 \%$ level according to Duncan's multiple range test. Calculations for significance were made only within groups.

Chloroform-methano

d Chloroform phase $(0.05 \mathrm{ml})$ representing $0.025 \mathrm{~g}$ fresh plant naterial diluted with $0.10 \mathrm{ml}$ water and $0.35 \mathrm{ml}$ methanol. $\mathrm{ml}$ ) combined to represent 0.025 g fresh plant material and diluted with $0.35 \mathrm{ml} \mathrm{methanol}$. 
M. officinalis were compared in Group I while the chloroform phases of the 2 species were compared in Group II. Disks treated with the water-methanol phase of $M$. officinalis leaf extracts were fed upon to at significantly ( $1 \%$ level) greater extent than disks treated with a comparable solution from $M$. infesta leaves or with the water-methanol solvent alone. Disks treated with the chloroform phase (Group II) from $M$. officinalis and $M$. infesta leaf extracts were essentially alike, but this fecding was significantly greater than that observed on the blank disks treated only with the chlorolorm-methanol-water solvent. These data provide evidence that the compounds responsible for differences in weevil resistance between the 2 species exist in the water-methanol phase, and therefore the compounds are probably hydrophilic in nature.

Direct comparisons of the water-methanol and chloroform phases of extracts from each species also are given in Table 1 (Group III and IV). Each of the 2 groups consisted of 3 feeding tests with 3 treatments or comparisons. In a comparison of the watermethanol and chloroform phases from M. officinalis leal extracts (Group IV) the weevils fed upon disks treated with both phases, but they showed a decided preference for the disks treated with the chloroform phase. In the case of $\boldsymbol{M}$. infesta leaf extracts (Group III), the weevils fed appreciably only on the chloroform phase. No significant difference was noted between the water-methanol phase of $\boldsymbol{M}$. infesta extracts and the solvent check. Although the weevils prefer the chloroform phase to the water-methanol phase in a clirect comparison, the chemical difference (s) responsible for resistance or susceptibility in the 2 species resides in the water-methanol phase.

Since the weevils showed a decided preference for the chloroform phases, these were compared with the combined chlorolorm and water-methanol phases from each species. The data in Table 2 are the summary of results from feeding trials involving the following treatments: (1) chloroform-methanol-water blank, (2) cliloroform phase from $M$. infesta, (3) chloroform phase from M. officinalis, (4) combined water-methanol and chloroform phases from $M$. infesta, and (5) combined phases from $M$. officinalis. In the direct comparison of chloroform phases and combined chloroform and water-methanol phases for the 2 species, disks impregnated with the chloroform phase from $M$. infesta did not differ significantly from disks treated with the chloroform phase from $M$. offcinalis or with the combined phases from $M$. infesta Disks treated with the combined chloroform and water-methanol phases from $M$. officinalis, on the other hand, were fed upon significantly ( $1 \%$ level) more than any other disks.

Thus, despite the weevils' apparent preference for the chloroform phase over the water-methanol phase (Table 1, Group IV), the combined phases from $M$ officinalis leaves were much preferred to the chloro form phase alone. A synergistic stimulation of fecding, involving constituents of both phases, seems possible.

The foregoing data demonstrate that a workable and reliable bioassay has been developed for detecting chemicals in sweetclover extracts that stimulate or deter feeding by adult sweetclover weevils. Use of this method in preliminary studies has shown that chemical differences do exist between the weevil. susceptible species, $M$. officinalis, and the resistant species, $M$. infesta.

AckNowL.FDGiment. - The technical assistance of Henry J. Stevens, Entomology Research Division Agr. Res. Serv., USDA, and Gary L. Beland, Graduate Research Assistant, Department of Entomologr. University of Nebraska, is gratefully acknowledged.

\section{REFERENCES CIITED}

Bligh, E. G., and W. J. Dyer. 1959. A rapid methot of total lipid extraction and purification. Can. J. Biochem. Physiol. 37: 911-17.

Gross, A. T. H., and G. A. Stevenson. 1964. Resistance in Melilotus species to the sweetclover weevil (Sitonn cylindricollis.). Can. J. Plant Sci. 44: 487-8.

Manglitz, G. R., and H. J. Gorz. 1964. Host-range studies with the sweetclover weevil and the sweet clover aphid. J. Econ. Entomol. 57: 683-7.

Radcliffe, E. B., and F. G. Holdaway. 1964. Sw'eet. clover resistance to weevil attack. Minnesota Farm \& Home Sci. Fall Issue: 5-7.

Thorsteinson, A. J. 1955. The experimental study of the chemotactic basis of host specificity in pliytophagous insects. Can. Entomol. 87: 49-55. 